\title{
Evaluation of fungicides against leaf spot of turmeric caused by Colletotrichum capcisi
}

\author{
SARODEE BORUAH ${ }^{* 1}$, M. BORAH ${ }^{1}$, D. BARMAN ${ }^{2}$ AND PRANAB DUTTA ${ }^{1}$
}

${ }^{1}$ Department of Plant Pathology, Assam Agricultural University, JORHAT (ASSAM) INDIA

${ }^{2}$ Department of Agronomy, Assam Agricultural University, JORHAT (ASSAM) INDIA

\section{ARITCLE INFO}

Received : 08.08 .2014

Revised : 21.01.2015

Accepted : 05.02 .2015

KEY WORDS :

Colletotrichum capsici, Fungicides, Leaf spot, Turmeric

*Corresponding author:

Email: sarodeeboruah@gmail.com

\begin{abstract}
Fungicides are the common tool for the management of leaf spot of turmeric crop caused by Colletotrichum capsici (syd.) Buttler and Bisby. The efficacy of six (6) fungicides viz., blitox50, carbendazim, carbendazim 12 per cent + mancozeb 63 per cent, captan, mancozeb and matalaxyl were evaluated at minimum dose against the pathogen. Amongst the fungicides, carbendazim 12 per cent + mancozeb 63 per cent @ 0.2 per cent was found significantly effective in inhibiting the mycelial growth $(4.47 \mathrm{~cm})$ of the pathogen. Effect of carbendazim in inhibiting the mycelial growth of $C$. capsici was found next $(2.90 \mathrm{~cm})$ to carbendazim 12 per cent + mancozeb 63 per cent. Mancozeb $(1.80 \mathrm{~cm})$ and captan $(1.62 \mathrm{~cm})$ also showed effective results as compared to matalaxyl $(1.0 \mathrm{~cm})$.
\end{abstract}

How to view point the article : Boruah, Sarodee, Borah, M., Barman, D. and Dutta, Pranab (2015). Evaluation of fungicides against leaf spot of turmeric caused by Colletotrichum capcisi. Internat. J. Plant Protec., 8(1) : 57-60. 